\title{
FAMILY AND EDUCATION
}

\author{
Pascariu Constantin Cătălin \\ PhD, Lect. University of Oradea, Romania, costi_pascariu@yahoo.com
}

\begin{abstract}
From the etymological point of view, the concept of education has its origins in the Latin roots "educoeducare" (to grow, to take care of), respectively "educo-educere", which means to lead, to guide. Education is a leading action. This statement emphasizes the etymological meanings, in the sense that any educational act involves directing the evolution of the individual to higher stages, defined by independence, autonomy, ability to integrate/adapt to the social environment (I. Comanescu, 1996). From a sociological point of view, the concept of education designates a complex activity that ensures the transmission of the accumulated information and the experience gained by humanity through a sequence of actions exercised consciously, systematically and organized by the educator on the educated, in order to transform him in an active and creative personality, corresponding to the historical-social conditions (A. Cazacu, 1992).

How much does the education within the family mean today? It is a question that requires time for reflection, but we can also say that the concept of family refers to the family as a group of people directly related by kinship relationships, whose adults take responsibility for raising children, a responsibility that includes in it also its educational forms. This article comes to check certain philosophical reflections. We can say about education that it survives after everything that has been learned has been forgotten. Education is the best provision we can make for old age. The family is an important and responsible factor in education. Parents lead it and are responsible for it in front of society, for their happiness, and their children's lives. Education is the means by which parents pass on their own flaws or positive aspects to their children.
\end{abstract}

Keywords: family, education, respect, solidarity.

\section{INTRODUCTION}

Family education can be defined as "any learning activity in which children and adults from a family take part, the results of whom target both parties and which contribute to the culture of family learning".

Studies show the positive and economically efficient impact of the family education on the school outcomes and social inclusion. However, these findings are rarely understood, even by the school institutions. Therefore, in most cases, family education is not perceived by teachers as an essential activity, but as an "additional luxury", and in the event of additional pressures, teachers may feel that they cannot afford to invest in it.

An important factor in children's success is the love of their parents. Respect must also exist, as well as the parental care.

Regardless of the language spoken and belonging, the involvement of parents has a positive impact on children's school development. Even in the case of children or adolescents with serious behavioral problems (delinquency, alcoholism), the constant involvement of both parents has brought significant results in recovering children and increasing their school results.

The family is the environment that directly influences the child's development. Parents are the first "teachers" in their lives for children, they influence the growth and type of behavior of the child through involvement in his education and training, parents lay the foundations that the child needs to develop and build a successful future. 
The individual, within the family, develops multilaterally, having the advantage of including several branches of activity. A healthy and toned environment will help a better understanding of society, humanity, a good education will help create an individual useful to society who has its own personality and will benefit from enrichment with new values and concepts (Oprea, 2019).

\section{FAMILY FUNCTIONS}

\section{The educational function}

The family, as the primary unit of any human social organization, is called, together with other social factors, to contribute to the achievement of the objectives of educational-formative action, carried out with children, as representing, as Merton (1957) calls it, "the transmission belt of cultural norms, from generation to generation".

Mitrofan (1984) considers that "parents exert educational influences on children in two ways: directly, through more or less organized actions, using methods and techniques and indirectly, through methods of conduct and the existing psycho-social climate in the family."

The family is a propitious framework to the transmission of values (terminal values and tools), norms and educational attitudes, embedded by some sociologists (Bourdieu and Passeron, 1964) in a more comprehensive concept, "pedagogical ethos" (Florescu, 2016).

Mitrofan (1984) mentions, within this general educational function, the following sub-functions: psycho-moral (formation of positive traits and attitudes), instructional-formative (children receive information), sociointegrative (the way the child interacts with other people from family group and outside the group) and cultural-formative (cultivating the appetite for cultural-spiritual development and creative abilities).

Educational values, as Kohn (1969) points out, are transmitted differently, depending on the occupational status and differentiated to children, which is why we can talk about school success syndrome, differentiated according to social classes (Rosen, 1956).

The educational function is sometimes exercised also by the extended family. The traditional model of the extended family involves a cohabitation of several generations, which favors the emergence of a stronger emotional relationship between grandparents and grandchildren, implying an educational role on their part. It was found that the emotional relationship is stronger between grandparents (especially maternal grandparents) and grandchildren, implying an intimacy without constraints and normative regulations (such as the relationship between parents and children), which is why they become, for each other, a moral and material support, a confessor, etc. The studies performed did not highlight a specific role of grandparents or relatives in the education of children, but only one of supplementing the parental role (Stănciulescu, 1997).

The function of the family, of cultivating Christian spiritual, moral and religious values, takes place, normally, in families formed on solid foundations, on mutual trust and respect and on the fear of God. The best education is a happy and harmonious life in the family, says Achimescu (1995), who quotes St. John Chrysostom: "When you come home find not only material food, but also spiritual food... And so that your house becomes a church."

\section{Economic function}

This function is the main indicator of balance in a family, as solving economic problems contributes, implicitly, to maintaining an organized family, with real possibilities to solve all obligations, both to itself and to society (Barth, Ciobanu, 2017). Being dependent on the type of society and the level of its socio-economic development, the economic function has changed considerably over time.

\section{Biological function}

The socio-biological function includes three basic sub-functions: sexual, reproductive, and physical care or protection. In order to ensure the stability of human society, it was necessary for sexuality to be regulated in a manner accepted by society. This phenomenon has occurred in all existing cultures, in different forms and degrees. Mus grave (quoted after Stănoiu and Monica Voinea, 1983) stated that “... there are very strong impulses in the sexual behavior of most people and any organized society wants to control this area of behavior. No matter what the chosen family system is, sexual requirements are, in one form or another, within the family."

\section{Solidarity function}

The family, as a social unit, implies a complex system of relationships between members, with mutual rights 
and obligations. The basic condition for the cohesion of the "success" of family life is the "convergence" of the action of all members of the group in achieving a common goal. Any disorder in these relationships endangers the stability of the family (Barth, 2019). Within the nuclear families (husband and wife), solidarity concerns the relationships between them, analyzed also in terms of the distribution of authority in the family and the way in which the division of family roles is structured.

\section{FAMILY TYPES AND THEIR INFLUENCES ON THE CHILD}

Family sociology uses a variety of terminology to cover the diversity of concrete situations that fall within the scope of the notion of family. Thus, a distinction is made between:

a) The nuclear family - consisting of parents and their unmarried children, and the extended family, resulting from the reunion of several nuclear families. The nuclear family is a structure currently found in most modern human communities.

b) The extended family - more common in traditional communities - includes direct and collateral relatives, three or more generations.

c) Family of origin - family of origin, in which the person is born and raised, made up of parents, brothers and sisters, also called guidance family, and the family of procreation, conjugal, created by their own marriage, consisting of spouses and children; as can be seen, the composition of the two types of family is relatively identical, and what differentiates them is the perspective from which they are defined: that of the person who looks to the past, to his origin and that of the person who "abandoning his origin", he builds his present and future, starting his own family, giving birth to children, in a new family of origin.

d) The family of residence, consisting of people living together and interaction families, characterized by mutual exchanges of products, visits.

e) The normal family - which fulfills all the functions of the family - the biological function, the psychosocial and educational function, as well as the economic function - and the disorganized, vulnerable family, in which one or more functions are deficient.

f) Patriarchal, matriarchal and egalitarian families - thus classified according to the manner of exercising authority. In the patriarchal system, authority is held by the oldest man or by husband. In matriarchal systems, authority is exercised by the older woman or by the wife. At present, the egalitarian system is predominant, in which family power and authority are shared equally between husband and wife.

\section{REFERENCE LIST}

Achimescu, N., (1995), Familia creștinã, între tradiție și modernitate. Considerații teologico-sociologice, in "Familia creștină azi", Trinitas Publishing House, Iași.

Barth, K.M., (2019), The role of multicultural projects in the development of the personality of children with special educational needs, in "The role of intercultural communication in adapting ethnic groups to the European Union Social Space", edt. K.M Barth, M. Brie, D. Dărăbăneanu, I. Polgar, Lambert Academic Publishing, Ltd., pp. 307-315.

Barth, K., Ciobanu, N.R., (2017), Mass media influence upon personality development of children, in "Education and Applied Didactics", Vol. I, Issue 1, 2017, Publishing House of University of Oradea, pp. 7-25.

Bourdieu, P., Passeron, J.C., Les Héritiers., (1967), Les étudiants et la culture, Les Editions de Minuit, Paris. Comănescu. I., (1998), Prelegeri de pedagogie, Imprimeria de Vest Publishing House, Oradea.

Cazacu A., (1992), Sociologia educaţiei, Hyperion Publishing House, Bucharest.

Florescu, M.C., (2016), Managementul problemelor disciplinare la clasele pregătitoare, in "Joc-invățarecooperare la clasele pregătitoare", coord. Popa C., EDP, Bucharest, pp. 109-119.

Kohn, M.L., (1969), Class and Conformity: a Study in value, Second Edition, Chicago, Univ. of Chicago Press, pp. 45-77.

Merton, R.M., (1957), Social Theory and Social Structure, Ed. 2, Glencoe, III. 
Mitrofan, N., (1984), Dragostea și căsătoria, Stiințificã și Enciclopedică Publishing House, Bucharest.

Oghurn, W.J., Tibbits, C., (1953), The Family and its Functions, McGraw-Hill Publishing House, New York.

Oprea, I. M., (2019), Family and the Challenges of the Contemporary Society, in "Astra Salvensis", VII, no. 14, Beclean, pp. 195-200.

Rosen, B.C., (1956), The Achievement Syndrome: A Psycho-Cultural Dimension of Social Stratification, in "American Sociological Review", 21, Published By: American Sociological Association, pp. 203-211.

Stănciulescu, E., (1997), Sociologia educației familiale, Polirom Publishing House, lași. 